\title{
Archetype as the communication tool of national cultures: on the question of the typological similarity of Russian and Hungarian literatures (based on the short story "Student" by A.P. Chekhov and the novel "Two Beggar- Students" by Mikszáth Kálmán)
}

\author{
Viktoriya Kondrateva ${ }^{1 *}$, and Angelika Molnar ${ }^{2}$ \\ ${ }^{1}$ Rostov State University of Economics, Iniciativnaya str. 46, Taganrog, 347936, Russia \\ ${ }^{2}$ University of Debrecen, Debrecen, University st.1, 4032, Hungary
}

\begin{abstract}
The study aim is finding of interaction between national and universal features in works by the Russian and the Hungarian writers, shift from ethnocultural to common content as the specific communication tool of different national literatures. Methodology. Methodological study base is the system unity of cultural and anthropological, structural semiotic and typological, comparative and mythopoetic methods. Results. A.P. Chekhov and K. Mikszáth works include national specificity as well as universal motives and images. Revealed by comparative analysis writers common archetypical platform speaks to common great-roots of their work. Although this approach doesn't exclude, even involves studies of individual artistic manner, biographic, historical and cultural impact. The common typological row is the fact of world literature phenomenon. Human inward life repeats in specific forms, particularly in archetypes. Comparison of the novel by K. Mikszáth "Two Beggar-Students" and the story "Student" by A.P. Chekhov shows the common typological row (characters status, images of home, road, way and transitivity motives) and simultaneously manifestation variety. Conclusion/recommendations. Convergence of motives and imaginary components in works by $\mathrm{K}$. Mikszáth and A.P. Chekhov intensifies authentic features of the writers. The typological row allows seeing similarity and understanding better difference between the Russian and the Hungarian writers.
\end{abstract}

\section{Introduction}

In Russian science today there is an often shared idea about archetype literary nature, which significantly changes understanding of universals. It is particularly typical for studies in mythopoetics, above all, V.N. Toporov, E.M. Meletinsky and their followers. The work of Meletinsky "Literary archetypes and universals" and multi-author book with the same title,

* Corresponding author: viktoriya vk@mail.ru 
published under his editorship [5], mainly devote to archetypes in the Russian classical literature (N.V. Gogol and other). V.N. Toporov in his monograph "Myth. Ritual. Image. Studies in Mythopoetic Sphere" [24] and in other works studies "universal mythopoetic schemes" in works of Dostoevsky, Mandelshtam and other authors. Yu.V. Domansky writes about the crucial role of archetypical meanings in works of Pushkin and Chekhov. On the way to reality the world knowledge of the artist forms adherence to literature and its classical pieces. As the Dutch investigator W.G. Weststeijn says, literature study can turn to "the frames theory formed in cognitive sciences": a man, faced something new, chooses in his memory prepared for new situation structure.

Archetypes study allows making creative dialog of art considerably detailed. The issue of genetic and typological connections between national literatures, particularly between the Hungarian and the Russian literatures has not been theoretically settled.

In the base cultural stability has the solid system, determined by regional specificity, ethnoculture and traditional culture. However, the investigators, involved in studying dialog phenomenon between Russian and Hungarian literatures, are limited by reception issued. We initiate that the poetics study of a literature piece in the modern Philology is impossible to imagine without adherence to the categories "big time" and "genre memory", theoretically proved in works by M.M. Bakhtin. Effectiveness of these categories use in the literature study works of the latest decades means that they make it possible for an investigator not only to expand the context presenting any writer's creative work, but also to appeal to traditional culture, oral art roots, and to its archetypes.

\section{Methodology}

Methodological study base is the system unity of cultural and anthropological, structural and semiotic, structural and typological, comparative and methods. The main message of the comparative method is the idea of unity and pattern of world literary and social processes $[1,3,17,19]$.

Methodological study bases for literary constancies study in the Russian science were set in 19th century, first of all, in the comparative and historical school (A.N. Veselovsky). Appeal to literary constancies at the present time more often has the cross-disciplinary study style with the methodology aimed at integrity of cross-scientific studies for different scientific fields. The literature study methodology with historical poetics and mythopoetics, structural and semiotic, structural and typological, intertextual approaches appeared to be more productive $[4,18,20]$.

\section{Results}

The discussion about the dialog between the Russian and Hungarian literatures is not accidental. The Hungarian literature is known to have passed difficult way of establishment. Long time it was influenced by German, French as well as the Russian literature. The last one contributed significantly to the Hungarian literature. The most interesting there Russian writers for a Hungarian reader are I.S. Turgenev, I.A. Goncharov and A.P. Chekhov. As a result, there is a question about genetic and typological connections between the Russian and the Hungarian literatures; we suppose to reveal it on a basis of the novel by K. Mikszáth "Two Beggar-Students" and the short story by A.P. Chekhov "Student". Scientific study innovation is in the way studying the Russian and the Hungarian writers taking into consideration regional, national, and common human content, focusing on anthropological factor in the modern common humanitarian paradigm. 
The novel by Kálmán Mikszáth "Two Beggar-Students" (1886) and the short story by A.P. Chekhov "Student" (1894) have key differences: the novel Mikszáth is a romantic written in ironic fairy manner story about two brothers orphans István (Pisto) and Laslo (Latsi); the short story by A.P Chekhov is a realistic work, based on philosophic and psychological story with clear existential motives, disappointment about world order, loneliness and despair, beliefs loss and after all - soul treatment, True Being understanding and returning to God.

Different from the first sight these literature pieces have similarities. The common feature of the works is the main characters - students, young people, beggars, suffering world inequality. K. Mikszáth emphasizes the student status of the heroes in the title despite social status changes of Laslo and Pisto during the story. A.P. Chekhov is known to think of the title "In the Evening" for his work but finally chose the word "student". Taking into consideration the fable of the works, it becomes obvious that both authors pay attention to transitivity and borderline of the heroes status. The student status in the works of the Hungarian and the Russian writer has more likely conditional allegorical meaning, showing individuality setting.

Both works have image of way playing plot building role. Both characters of Mikszáth and Chekhov are on their ways. They have their own life ways. Characters of Mikszáth are orphans at the beginning, then they are adopted son, their new mother gives them new names, after it Latsi and Pisto become students of the seminary, wanderers and finally they are fighter for Hungary liberation.

The mythologeme "way" is one of "the most important space-time indicators or more detailed as one more model of "specialization" for time" [14]. Many mythoethical spaces have the mythologeme way not only for a real road meaning, but it is used as some rules guide, laws list, as a study, a religious study, religion [7, 8]. The way and its role in hero development do not only significantly determine a chronotope character in literary texts, but predetermine a genre type of these texts [14]. In addition, according to Yu. Pykhtina, geographical space is an obligatory attribute of the travelogue [25].

Almost all novel actions happen on the way, that is, the way chronotope is leading here. M. Bakhtin explains the importance of this component of literary reality: "...a road is a place of random meetings. One road "big road" is crossed in one time and space point by many various people with their space and time ways from all social classes, all statuses, all religions, nationalities, ages. People may accidentally meet here being divided by social hierarchy and distance, any contrasts may occur here, different destinies may interact and intertwine. There is specific match of space and time rows of human destines and lives, making complicated and detailed social distances, overcome here"[12]. So, this space allows occurring and acting of any events, it is a specific centrifugal point in the work, the place, where plot "knots" of the work are formed.

The way is the most important archetype in the human culture. Inner semantic way archetype field in the culture fully and excessively has not been comprehended yet. This image is very popular in the world culture and literature and it has similar, if not identical, universal features in different national cultures.

The way of both brothers is formed by fairy scheme logics. They have unique mind, strong physical power. According to fairy tale logics, due to brothers savvy their helpers appear surprisingly. The characters face seduction, betrayal, death, salvation, love and hero status gaining.

One of the main and very often actual meaning aspects for this archetype is the interpretation for way-road as the transitional space, both uniting and dividing the world into the world "here" and the world "there". Moving on the way is connected with status change [21]. 
It is important to note, that all transformations with characters of the novel by $\mathrm{K}$. Mikszáth happen exactly on the way: the most considerable transformations here are situations with initiation of the characters, resulted in moving from one social status to another one.

There is a leading role of particular paraphernalia, which marks characters belonging to any social class. The image of the saberbelt, won by Pisto in the competition may be used as an illustration (also it is a sort of challenge bringing the hero a prize). Only noblemen were allowed to carry a saber, but the hero is really ignoble. It is substantial that the author emphasizes this element in the novel text. Only after winning the saberbelt, Pisto realizes the issue "Why am I not noble?" [9] He starts talking about their life with Latsi, it would have been different if they had born noble. This paraphernalia becomes a type of push to life change for the characters. K. Mikszáth writes: "Presented saberbelt was hanging over Pisto's bed. It was a dangerous note. It caused indeed mad thoughts, making Latsi crazy soon" [9]. That is when the object from the other world goes to the characters, they start thinking of their powerlessness and make risky decisions to change their social place.

The way archetype causes development of the key motive: the motive of meeting or the motive of recognizing or non-recognizing [15]. So, the road space has fateful meetings of Latsi and Pisto with their future mother, with dying old dying lady and with Rozomak.

Only on the road aunt Dobosh cannot leave the idea about adoption of the poor orphans, after it, she finds and takes them from the roadside. While travelling, the students decided to enter the house of the dying old lady (here death can be interpreted as the transit from one world to another one, that is the way interpretation, more precisely the end of life and the way to another world), who bequeaths on death bed two dogs, heroes-helpers in the future. Only on the road the students meet Rozomak and at the crossroads students' life ways vary.

The essential role in the work of the Hungarian writer is for the old lady archetype (version of the old lady archetype is old man). E. M. Meletinsky defines interesting for us archetypical images as "wise man (lady)" - the top inward synthesis, harmonizing in old age conscious and unconscious soul parts" [5].

Two brothers meeting with the old lady becomes the turning point and seriously influences on the plot development. Laslo and Pisto have a test (they answer the questions of the dying old lady) and as reward for wise answers the brothers get from the old lady two dogs (white and black), one of them, as we know later, brings luck, another one brings loss. The old lady image can be interpreted as the next development step after the mother archetype. This cultural moment is implemented by K. Mikszáth in the plot: the old lady puts in her will absolutely unknown fellows like relatives. Besides, this archetype is complicated due to character functions from a magic fairy tale (that is logical because the work has magic elements of the plot. According to V.Ya. Propp, the dying old lady has the special role of a giver-provider [23].

The event in literature is going beyond the semantic field borders. In Mikszáth's novel the overlimit is done literally and symbolically. Pisto and Latsi really go to the big road searching for "place in the sun" (the heroes want to find the way of fortune and happiness), and symbolic overlimit is young heroes following their dream to become noble. Moreover, returning to mythopoetic text aspects, we see that Latsi and Pisto face the initiation ritual several times on their way, it is the contest and seduction challenge (by fortune and noble title).

The way archetype matches with the initial heroes' status - they are beggar students (pupils). A student is a man in borderline (at the border of semispheres, that is why, he is looking for his identity), he has not chosen the profession, the stratum to belong to and so on. A priori, he is a hero on his way, at life crossroads. He does not have social links, as a 
result, we see flexible "exterior" hero form, easy status change in the society. During the plot development we can follow easy social roles change of Mikszáth's characters.

With story progress in the novel "Two Beggar-Students" Latsi and Pisto manage easy shift from one stratum into another one after overcoming some challenges and completing of tasks. The characters easily change status into a new one and return the previous one. These situations are seen in the episodes, when Latsi gets the saberbelt as the symbol of high class and he becomes easily noble, or when the character finds a treasure, then he loses magically given fortune. Fast changing role shift is used in the plot line for Pisto: he becomes a hero, and then he is a criminal. And, finally, social role change forms a plot building function, when both brothers get fame of brave fighters being nation protectors, then they turn against and finally, when the truth wins, the brothers join their people.

Chekhov's short story "Student" has the way archetype to unite inside and outside structures of the works. In comparison with Mikszáth's novel Chekhov's work does not have tense action and outside engagement. The forefront is the inside plot - inner world of a character, his self-orientation trials in life. The focus of the Russian writer is character's perception; Ivan Velikopolsky is wearily wandering home after hunting, when he is in the arena of two nature forces fighting: light and darkness, with faith and without faith, despair and life miracle understanding. Chekhov's work has physical way matching with soul growing of the hero.

The key components of the way for the student of theological seminary: 1) the starting point of Ivan Velikopolsky's consciousness with the idea that nothing is changeable in this world, life burdens are compelling; 2) the middle of the way - fire set, where there is a meeting with two widows and the story about Christ's follower Peter is told; and 3) the rest part of the way of the hero having been already transformed. So, the way is divided into before fire set and after it.

Before fire set Chekhov's character is sure that everything does not have sense, nothing changes positively. But, according to road space rules, turning point of the plot is the meeting. The dialog of two widows smoothly turns to the evangelical story of Peter, Christ's Follower, who abandons several times the man he seems to be devoted to. Via the story of Peter's betrayal Ivan Velikopolsky tries to transmit the idea that there is lack of place for good, faithfulness, devotion: even "passionate, desperately" in love Christ's Follower denies three times his Teacher. Like Peter, Ivan passes denial, apostasy and abnegation. However, after reaction of the women, two widows, mother and daughter ("Vasilisa started crying, and her daughter was confused" [2]), the student suddenly understands that "having happened nineteen centuries ago the story refers to the present time - to both women and, probably, to the desert village, to himself, to all people." Twenty-year-old man gets the idea that "the past is connected with the present via endless chain of events, deriving from each other".

One of the typical for traditional culture perceptions is understanding that "a man must overcome the way of death, roam literally and then he becomes upgraded, alive again, survived after death" [16]. The time of Chekhov's short story is Easter Eve, the period that symbolically expresses the state of transitivity and upgrade simultaneously. Easter is connected with the idea of death overcoming, in literature - moral resurrection of a man.

At the end of the story Chekhov presents the images of river and crossing in two meanings - real and symbolic. On the one hand, the river image is the "symbol of time flow irreversibility", also "symbol of direction" matching the image of "endless chain of events, deriving from each other", on the other hand - this is the image for illustration ancient ideas about the border between worlds (alive and dead). Allegories allow understanding of Ivan Velikopovsky's turn from one opinion about the world to another one. Exactly during crossing Chekhov's character realizes his upgrade, now he turns to west, feeling happiness coming. 
The Hungarian and the Russian writers create the works, which have as a basis the road plot. Special meanings for the image of road as a cultural universal are implemented in transition and transformation of the characters. However, Mikszáth's road with accompanying motives forms outside dynamic plot, in Chekhov's short story this image is accompanied by inner moral transformation of the hero.

The Hungarian and the Russian writers have in their works the meaning of the image road generated mainly by home motive in direct and indirect meanings.

The story of K. Mikszáth's characters is the story of self-acquiring and finding of home. Home is interpreted in a broad sense, historical and cultural, historical and political meanings. In the end it is clear that the novel, written in adventurous historical style, is not only about adventures of two lucky brothers, but it is also about the way to independence, about self-determination of Hungarian people.

Chekhov's home in the short story has important meaning as well. The main character perception of home and family (rejection, reluctance to return there, the image of home itself, kept in mind by Ivan Velikopolsky) signifies that the hero is lost in the world. He does not have the starting point. The world, where he lives, seems to him endless chaos. Chekhov's character is shown in the existential situation searching for world sense, life sense, searching for world order, his own place in this world. He thinks about world order in the beginning of the story and comes to the conclusion that nothing has sense. The main reason of this meaninglessness is immutability of things in the world. According to $\mathrm{S}$. Kierkegaard, inward growth and inward formation are expressed, in terms of existential analytics, by three main behavior setting: esthetic, ethical and religious. In this regard, N. S. Kornyuschchenko-Ermolaeva states: "The target of all S. Kierkegaard's studies was desire for deep and real religious test of human being, demonstration of inevitability and need for men's choice of the way to God. The sequence and the order of S. Kierkegaard's stages are not random, two first stages, esthetic and ethical, are the sequential ways to the highest religious one. All three stages are united by despair, a man bound to on all these stages". [13]. Chekhov's short story has mainly religious setting. The character, like a prodigal son, returns to his Father's home. In this regard, home is interpreted not as physical space, not a house, but as metaphysical space, inward support, harmony, found by Chekhov's character in enlightenment, transformation of soul and spirit, in truth understanding.

With both writers their characters' way is the way home. Chekhov's desperate character after having lost heart and faith returns to God, Father in Heaven. Like a prodigal son, he finally finds his peace in his home allegorically. Mikszáth's characters are on their way home and author's emphasis ensures at the story end that home will be found by them.

Thus, Chekhov's works and Hungarian prose show universal motives on the one hand, on the other hand, they have national unique features.

Revealed by comparative analysis writers common archetypical platform speaks to common great-roots of their creative work. Although this approach does not exclude, even involves studies of individual artistic manner, biographic, historical and cultural impact. It seems to us, our simple and preliminary observation results in one more very important conclusion regarding modern literature ideas. According to I. O. Shaitanov, there are concepts "world" and "universal" literatures [6]. This "universal" literature, united national ones, was established in $20^{\text {th }}$ century mainly thanks to Chekhov's creative and artistic heritage.

\section{Conclusions / Recommendations}

The common typological row is the fact of world literature phenomenon. Human inward life repeats in specific forms, particularly in cultural universals and archetypes. The novel by K. Mikszáth "Two Beggar-Students" and the short story "Student" by A.P. Chekhov 
show the common typological row (characters status, images of home, road, and transitivity motive) and simultaneously manifestation variety.

Table 1. The common typological row (characters status, images of home, road, and transitivity motive) and simultaneously manifestation variety in the novel by K. Mikszáth "Two BeggarStudents" and the short story "Student" by A.P. Chekhov.

\begin{tabular}{|c|c|c|c|}
\hline \multirow{2}{*}{$\begin{array}{c}\text { An author, a } \\
\text { work }\end{array}$} & \multicolumn{3}{|c|}{ Components of a typological row } \\
\cline { 2 - 4 } $\begin{array}{c}\text { Inner semantic } \\
\text { field of a } \\
\text { component }\end{array}$ & student & $\begin{array}{c}\text { Course of life, a } \\
\text { space of } \\
\text { challenges and } \\
\text { status change }\end{array}$ & $\begin{array}{c}\text { Home, first of all, is a } \\
\text { dwelling-place of a } \\
\text { person, his own world }\end{array}$ \\
\hline $\begin{array}{c}\text { K. Mikszát } \\
\text { "Two Beggar- } \\
\text { Students" }\end{array}$ & $\begin{array}{c}\text { Border state, person formation, } \\
\text { transformation }\end{array}$ & $\begin{array}{c}\text { Transitivity, } \\
\text { challenges, } \\
\text { initiation, status } \\
\text { change; road } \\
\text { encounter causes } \\
\text { life changes }\end{array}$ & $\begin{array}{c}\text { Home as } \text { own world, } \\
\text { home as a family and } \\
\text { motherland }\end{array}$ \\
\hline $\begin{array}{c}\text { A. P. Chekhov } \\
\text { "The Student" }\end{array}$ & $\begin{array}{c}\text { Bransitivity, } \\
\text { spiritual } \\
\text { transformation, } \\
\text { road encounter } \\
\text { causes changes in } \\
\text { worldview }\end{array}$ & $\begin{array}{c}\text { Home as a spiritual } \\
\text { support, coming back } \\
\text { to faith }\end{array}$ \\
\hline
\end{tabular}

There is inside differentiation of literature development within the common typological row. It makes possible to see uniqueness of events and processes in this row. Convergence of motives and imaginary components in works by K. Mikszáth and A.P. Chekhov intensifies authentic features of writer artistic manner. The typological row system allows better understanding of difference between the Russian and the Hungarian writers.

The reported study was funded by RFBR and FRLC, project number № 20-512-23010.

\section{References}

1. A. Behdad, D. Thomas, A Companion to Comparative Literature (Blackwell Publishing Ltd, 2011)

2. A. Chekhov, Student, Complete works and letters in 30 volumes, 8, 306-309 (1977)

3. C. Domínguez, H. Saussy, D. Villanueva, Introducing Comparative Literature: New Trends and Applications, Routledge (2014)

4. D. Damrosch, What Is World Literature? (Princeton University Press, 2018)

5. E. Melitinsky, Analitical psycology and origin of archetypical plots (1994)

6. I. Shaitanov, Literature Issues, 6, 13-33 (2018)

7. I. B. Rubert. Humanities \& Social Sciences, 12, 2982-2988 (2015)

8. J. Garry, Archetypes and Motifs in Folklore and Literature: A Handbook. Routledge (2011)

9. K. Mikszáth, Two Beggar-Students (1987)

10. M. Larionova, Inskrypcje. Półrocznik, 1(14), 9-14 (2020), doi:10.32017/ip2020.1.1

11. M. Larionova, Inskrypcje. Półrocznik, 1(12), 11-17 (2019), doi:10.32017/ip2019.1.1 
12. M. Bakhtin, Epic and Novel, 11-176 (2000)

13. N. Kornyuschchenko-Ermolaeva, Kierkegaad on a question of existence and loneliness, Izvestia Tomsk Polytechnic University, 309(8), 244-249 (2006).

14. N. Nikipelova, T. Shehovtsova, A.P. Chekhov's work (Poetics, origin, influence) (2000)

15. N. Moore, The Archetype of the Way, Journal of Analytical Psychology, 28(2), 119140 (2013)

16. O. Feidenberg, Myth and Ancient Literature (1978)

17. R.Ph. Bekmetov, Journal of Language and Literature, 2, 141-145 (2015)

18. S. Deckard, N. Lawrence, N. Lazarus, G. Macdonald, Combined and Uneven Development: Towards a New Theory of World-Literature (Liverpool University Press, 2015)

19. S. T. de Zepetnek, Comparative Literature and Culture (Purdue University Press, 2011)

20. S. Bassnett, Reflections on Comparative Literature in the Twenty-First Century. Comparative Critical Studies, 3, 1-2 (2011)

21. T. Kirsch, V. Rutter, T. Singer, Initiation: The Living Reality of an Archetype. Routledge (2016)

22. V. Kondratyeva, Inskrypcje. Półrocznik, 1(14), 71-76 (2020), doi:10.32017/ip2020.1.8

23. V. Propp, The Historical Roots of Fairy-tales (2000)

24. V.Toporov, Space and a text (1983)

25. Y. G. Pykhtina, P. A. Yakimov, M. A. Konova, Vestnik Slavianskikh Kul'tur, 50, 229245 (2018) 